Original Research Paper

\title{
Local Wisdom of the Rantau Panjang Community, Simpang Hilir District, Kayong Utara Regency in Utilizing Medicinal Plants
}

\author{
Muhammad Saupi ${ }^{1}$, Hikma Yanti ${ }^{1}$, Yeni Mariani ${ }^{1 *}$ Fathul Yusro ${ }^{1}$ \\ ${ }^{1}$ Forestry Faculty, Tanjungpura University, Pontianak, Indonesia
}

\author{
Article History \\ Received : August $14^{\text {th }}, 2021$ \\ Revised : August $30^{\text {th }}, 2021$ \\ Accepted : September $14^{\text {th }}, 2021$ \\ Published : September $21^{\text {th }}, 2021$ \\ *Corresponding Author: \\ Yeni Mariani, \\ Forestry Faculty, Tanjungpura \\ University, Pontianak \\ Email: \\ yeni.mariani81@gmail.com
}

\begin{abstract}
Medicinal plants for modern society today are still one of the alternative options in healthcare treatment. This condition is due to the local culture, tradition, and wisdom of a group of people that are still solid and thick. This study aims to analyze the types of medicinal plants used by the community in Rantau Panjang, Simpang Hilir District, North Kayong Regency. This research uses the survey method by conducting interviews with the community and identifying medicinal plants in the field. A sampling of the people who became respondents was done with a purposive sampling technique. The total number of respondents is 333 people distributed in several sub-village, namely Sepakat Jaya 71 people, Tembok Baru 65 people, Ampera 37 people, Makmur 61 people, Sinar Palung 25 people, Kebal Manuk 12 people, Sinar Selatan 35 people and Siput Lestari 27 people. The data obtained were analyzed for Use Value (UV) and Fidelity Level (FL). The village community of Rantau Panjang utilizes 69 types of medicinal plants, with the predominant plant family is Zingiberaceae. The highest use of plant parts is leaves (37.68\%), the most common method of processing is boiled (57.97\%), and the most extensive way of use is drunk as much as $(60.86 \%)$. The plants with the highest UV values are turmeric (Curcuma longa L) (0.42), red liyak (Zingiber officinale Linn) (0.34), white turmeric (Curcuma zedoaria L) (0.28), and betel (Piper betle L) (0.22). The types of plants have the highest FL value (100), namely simpur, ketumbar, sawo, leban, pulai, jantung pisang, bunga raya, alalang, durian, nipah, kopi, selo daging, keladi, paku ikan, pegage, kumis kucing, mahkota dewa, belange, belimbing pelunjuk, asam jawa, andong, limau sambal, jambu biji, lidah buaya, pinang, leban, mentimun, daun salam, mentimun, manggis, bajakah, cempedak, pandan wangi, pasak bumi, tebu merah, jengkol, cengkodok, anggrek dan ketepeng.
\end{abstract}

Keywords: Local wisdom, medicinal plants, Rantau Panjang village

\section{Pendahuluan}

Tumbuhan obat bagi masyarakat modern saat ini masih menjadi salah satu alternatif pilihan dalam proses pengobatan yang mereka lakukan. Hal ini dikarenakan masih kuat dan kentalnya budaya, tradisi dan kearifan lokal yang dimiliki oleh suatu kelompok masyarakat. Selain itu, adanya keinginan untuk kembali menggunakan bahan alam dalam proses pengobatan menjadi salah satu trend yang terjadi saat ini karena munculnya kesadaran masyarakat terhadap efek samping yang ditumbulkan oleh obat sintesis (Yusro et al., 2020).
Masyarakat di Kalimantan Barat memiliki beragam kearifan lokal dalam memanfaatkan tumbuhan obat, baik dari aspek suku (Pranaka et al., 2020; Sari et al., 2021; (Yusro et al., 2020a) aspek kelompok penyakit (Ardiana et al., 2019; Rania et al., 2019; Yusro et al., 2021) ataupun aspek kewilayahan seperti desa ataupun wilayah sekitar hutan (Aminah et al., 2016; Sauji et al., 2019; Yusro et al., 2020). Kearifan lokal tersebut perlu untuk dipertahankan agar tidak hilang pada masa yang akan datang, dan untuk wilayahwilayah lain di Kalimantan Barat yang belum dilakukan kajian perlu untuk dikaji keragaman kearifan lokal yang mereka miliki. 
Kearifan lokal masyarakat di Kalimantan Barat khususnya di Kabupaten Kayong Utara dalam memanfaatkan tumbuhan obat beberapa diantaranya telah di dokumentasikan seperti yang dilaporkan oleh Aminah et al., (2016) di desa Sejahtera, Ardiana et al., (2019) di desa Teluk Batang, Sauji et al., (2019) di desa Gunung Sembilan, Rania et al., (2019) dan Yusro et al., (2020) di desa Masbangun. Namun, hingga saat ini kearifan lokal dalam memanfaatkan tumbuhan obat oleh masyarakat di desa Rantau Panjang Kecamatan Simpang Hilir belum dilaporkan.

Desa Rantau Panjang berlokasi tidak jauh dari kawasan konservasi Taman Nasional Gunung Palung (TNGP). Keberadaannya yang dekat dengan hutan menjadikan mereka mengenal dan memanfaatkan jenis-jenis tumbuhan untuk berbagai macam keperluan, salah satunya adalah sebagai tumbuhan obat. Selama ini, pengetahuan yang mereka miliki disampaikan dan diajarkan kepada anak cucu meraka secara lisan saja, dan belum didokumentasikan. Kekhawatiran akan hilangnya pengetahuan mereka tentu menjadi perhatian bagi kita semua, sehingga perlu untuk dilakukan penelitian dan pencatatan kearifan lokal yang mereka miliki dalam memanfaatkan tumbuhan obat, baik tumbuhan obat tersebut berasal dari hutan ataupun tumbuhan yang sudah dibudidayakan oleh mereka di lingkungan sekitar. Penelitian ini bertujuan untuk menganalisis jenis-jenis tumbuhan obat yang dimanfaatkan oleh masyarakat di Rantau Panjang Kecamatan Simpang Hilir Kabupaten Kayong Utara.

\section{Bahan dan Metode}

\section{Waktu dan Tempat Penelitian}

Penelitian ini dilakukan di desa Rantau

Panjang Kecamatan Simpang Hilir Kabupaten Kayong Utara (Gambar 1). Di desa Rantau Panjang terdiri dari 6 dusun yaitu Sepakat Jaya, Tembok Baru, Ampera, Makmur, Sinar Palung, Kebal Manuk, Sinar Selatan dan Siput Lestari. Waktu penelitian pada bulan September-Oktober 2020.

\section{Alat dan Objek Penelitian \\ Beberapa peralatan penelitian yang digunakan antara lain voice recorder (perekam}

suara), kamera, panduan wawancara (kuesioner) dan buku identifikasi tumbuhan obat (Yusro et $a l ., 2020)$. Adapun yang menjadi objek penelitian adalah semua jenis-jenis tumbuhan obat yang dimanfaatkan oleh masyarakat desa Rantau Panjang Kecamatan Simpang Hilir Kabupaten Kayong Utara.

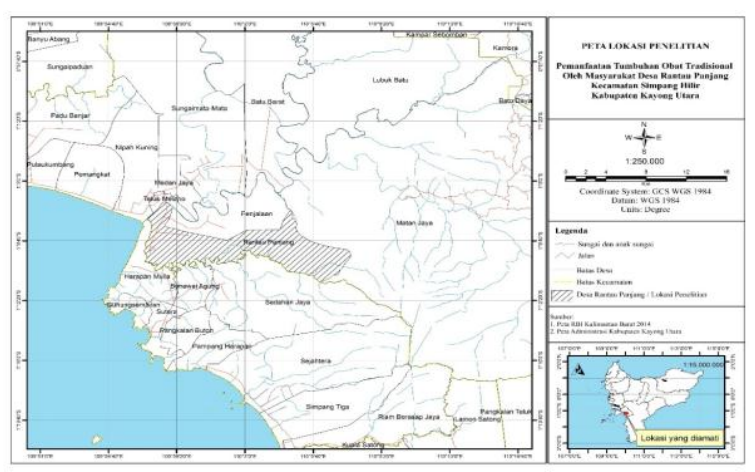

Gambar 1. Lokasi penelitian di Desa Rantau Panjang Kabupaten Kayong Utara

\section{Pengumpulan Data}

Penelitian ini menggunakan metode survey dengan melakukan wawancara terhadap masyarakat dan identifikasi tumbuhan obat dilapangan. Pengambilan sampel masyarakat yang menjadi responden dilakukan dengan teknik purposive sampling. Adapun kriteria responden adalah masyarakat desa Rantau Panjang Kecamatan Simpang Hilir Kabupaten Kayong Utara dan telah dewasa.

Besarnya jumlah responden berdasarkan pada rumus Slovin (Agung et al., 2018), dimana jumlah keseluruhan responden adalah 333 orang yang terdistribusi pada dusun Sepakat Jaya 71 orang, Tembok Baru 65 orang, Ampera 37 orang, Makmur 61 orang, Sinar Palung 25 orang, Kebal Manuk 12 orang, Sinar Selatan 35 orang dan Siput Lestari 27 orang. Data yang dikumpulkan berupa jenis-jenis tumbuhan obat yang dimanfaatkan, apa saja khasiat tumbuhan tersebut, bagaimana cara pengolahan dan penggunaannya.

\section{Analisis Data}

Data yang dikumpulkan berupa jenis-jenis tumbuhan obat yang dimanfaatkan, apa saja khasiat tumbuhan tersebut, bagaimana cara pengolahan dan penggunaannya. Data yang diperoleh selanjutnya dilakukan analisis berupa Use Value (UV) dan Fidelity Level (FL). Use 
value (UV) digunakan untuk menganalisis nilai manfaat dari suatu tumbuhan obat, dan dihitung dengan persamaan (Kigen et al., 2019):

Keterangan:

$$
U V=\sum \mathrm{U} / \mathrm{n}
$$

UV: Use Value (Nilai manfaat)

$\sum \mathrm{U}$ : Jumlah responden yang memanfaatkan suatu jenis tumbuhan

$\mathrm{n}$ : Jumlah keseluruhan responden

Fidelity Level (FL) digunakan untuk menganalisis jenis-jenis tumbuhan yang paling disukai/dipilih untuk pengobatan kategori penyakit tertentu, dan dihitung dengan persamaan (Tariq et al., 2015):

$$
\mathrm{FL}(\%)=(\mathrm{Ip} / \mathrm{Iu}) \times 100
$$

Keterangan:

FL : Fidelity Level (tanaman yang paling disukai)

Ip : Jumlah responden yang menyebutkan manfaat suatu jenis tumbuhan untuk kategori penyakit tertentu

Iu : Jumlah keseluruhan responden yang menyebutkan manfaat spesies untuk keseluruhan kategori penyakit

\section{Hasil dan pembahasan}

\section{Jenis-jenis Tumbuhan Obat dan Use Value (UV)}

Masyarakat desa Rantau Panjang

Kabupaten Kayong Utara hingga kini masih memegang teguh budaya dan tradisi yang mereka miliki dan hal tersebut ditunjukkan dengan kearifan lokal mereka dalam pemanfaatan tumbuhan obat. Terdata $93,39 \%$ masyarakat masih memanfaatkan tumbuhan obat, dan hanya $6,61 \%$ masyarakat saja yang tidak memanfaatkan obat.

Jenis-jenis tumbuhan yang digunakan sebagai bahan dalam pengobatan tradisional sebanyak 69 jenis yang terdistribusi dalam 42 famili (Tabel 1). Jenis-jenis tanaman ini lebih banyak jika dibandingkan jenis-jenis tanaman yang dimanfaatkan oleh masyarakat di desa-desa lain di Kabupaten Kayong Utara seperti 44 jenis di desa Teluk Batang (Ardiana et al., 2019), 27 jenis di desa Gunung Sembilan (Sauji et al., 2019), dan 24 jenis di desa Masbangun (Rania et al., 2019).

Jenis-jenis dengan nilai penggunaan (UV) tertinggi yaitu kunyit (Curcuma longa L) $(0,42)$, liyak merah (Zingiber officinale Linn) $(0,34)$, kunyit putih (Curcuma zedoaria L) $(0,28)$, dan sirih (Piper betle L) $(0,22)$. Tanaman kunyit oleh masyarakat desa Rantau Panjang digunakan untuk perawatan paska melahirkan, sakit perut, luka, dan melancarkan menstruasi. Kunyit diketahui mengandung berbagai macam komponen kimia yang berkhasiat sebagai obat seperti polyphenol, flavonoid, dan asam ascorbate (Tanvir et al., 2017). Selain dari komposisi kimia yang dikandungnya, penggunaan kunyit yang tinggi juga didukung oleh ketersediaannya yang mudah, hal ini karena dalam proses budidayanya tidak terlalu sulit dan mudah dalam pertumbuhannya.

Liyak merah atau dalam bahasa umumnya disebut jahe merah digunakan oleh masyarakat sebagai obat keseleo, bengkak, keputihan, sakit kepala, pilek, dan perawatan pasca melahirkan. Beberapa komponen bioaktif tanaman ini antara lain 194 jenis senyawa minyak atsiri, 85 jenis senyawa gingerol dan 28 jenis senyawa diarylheptanoid (Liu et al., 2019).

Kunyit putih dimanfaatkan oleh masyarakat sebagai bahan pengobatan terhadap batuk, perawatan pasca melahirkan, sakit tenggorokan, gatal-gatal, melancarkan menstruasi dan sakit perut. Komponen bioaktif yang dikandung tanaman ini antara lain sesquiterpenoid, monoterpenoid, epicurzeren, curzeren, curdion, curzerenon, debromofiliforminol, 1,8-cineol, $\beta$-sesquiphellandren, p-cymen, curcumenen, $\alpha$-phellandren, $\alpha$-terpinyl asetat, isoborneol, dehydrocurdion dan selina4(15),7(11)-dien-8-one (Liu et al., 2019).

Sirih digunakan untuk pengobatan sakit mata, melancarkan menstruasi, batuk, dan keputihan. Sirih banyak mengandung komponen bioaktif seperti phytol, acyclic diterpen alkohol, 4-chromanol, hydroxychavicol allylpyrocatechol, steroid, tanin, protein, asam amino, flavonoid, terpenoid, minyak atsiri, dan saponin (Nayaka et al., 2021).

Menarik dari hasil penelitian ini adalah dari keempat jenis tumbuhan dengan nilai UV tertinggi, tiga jenis diantaranya termasuk dalam famili Zingiberaceae. Tingginya penggunaan tanaman dari famili ini juga ditemukan pada wilayah lain di Kalimantan Barat seperti pada masyarakat suku Dayak Iban di Kabupaten Kapuas Hulu (Yusro et al., 2019), masyarakat desa Masbangun di Kabupaten Kayong Utara 
(Rania et al., 2019), dan suku Melayu dan Dayak Paus di desa Pengadang di Kabupaten Sanggau (Pradita et al., 2021). Famili Zingiberaceae dikenal luas sebagai tanaman yang memiliki kemampuan sebagai antibakteri (Irayanti \& Yadnya Putra, 2020), antioksidan (Danciu et al., 2015; Chumroenphat et al., 2019) dan anti kanker (Danciu et al., 2015).

\section{Bagian Tanaman yang di Manfaatkan sebagai Obat}

Bagian tumbuhan yang digunakan oleh masyarakat desa Rantau Panjang sebagai bahan obat untuk mengatasi beragam penyakit adalah daun, umbi, akar, buah, batang, rimpang, dan kulit. Bagian tumbuhan paling banyak digunakan yaitu daun 37,68\% dan buah 26,08\%, (Gambar 2). Jenis-jenis tumbuhan dengan bagian daun yang digunakan antara lain andong, ati-ati, bemban, bunge raye, daun salam, durian, jambu biji, ketiping, kacang, kumis kucing, lidah buaya, leban, mengkudu, mahkota dewa, sirsak, pepaya, pandan wangi, paku ikan, pereyak, pegage, sirih, selo daging, sirih merah, dan sirih pedas.

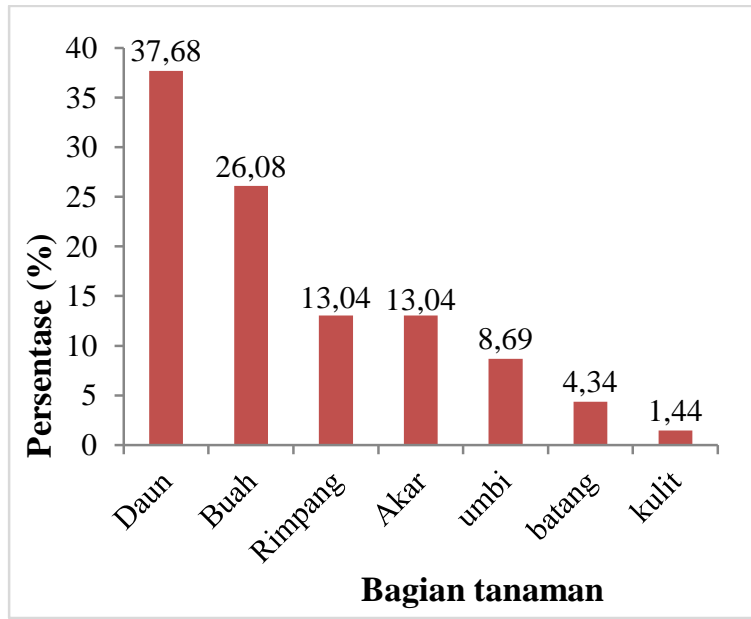

Gambar 2. Bagian tumbuhan obat yang dimanfaatkan masyarakat desa Rantau Panjang

Tingginya penggunaan daun juga ditemukan diwilayah lain di Kabupaten Kayong Utara seperti yang dilaporkan Ardiana et al., (2019) di desa Teluk Batang, desa Gunung Sembilan (Sauji et al., 2019) dan desa Sejahtera (Aminah et al., 2016). Tingginya penggunaan daun diduga karena mudah dalam proses pengolahan dan meramunya (Yusro et al., 2019), tidak menggangu kehidupan tanaman jika diambil secara kontinyu, dan memiliki kandungan bioaktif yang cukup banyak (Ardiana et al., 2019).

\section{Teknik Pengolahan Tumbuhan Obat}

Pengolahan tumbuhan obat yang dilakukan di masyarakat di desa Rantau Panjang sangat beragam, yaitu dengan cara ditumbuk, direbus, diparut, diperas, diremas, dilayur, dibakar, digiling, disalai dan tidak diolah. Cara pengolahan tertinggi dengan cara direbus $57,97 \%$, dan ditumbuk 18,84\% (Gambar 3).

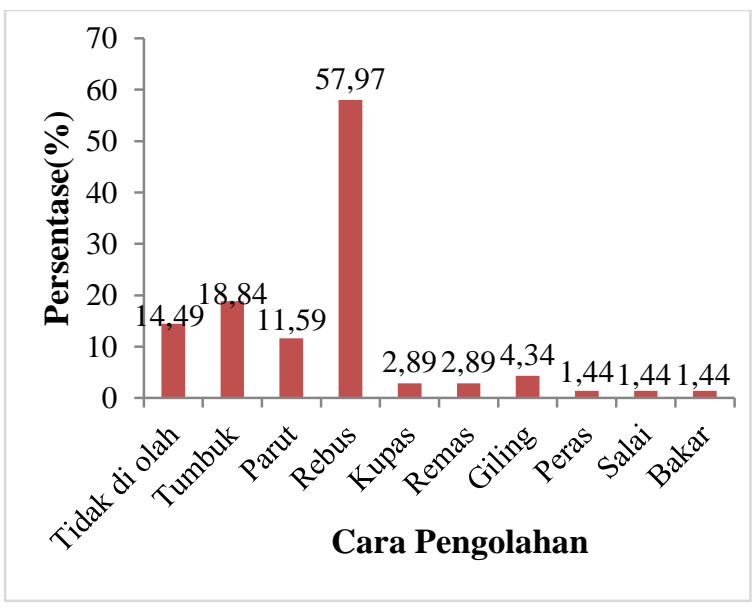

Gambar 3. Teknik pengolahan tumbuhan obat oleh masyarakat desa Rantau Panjang

Merebus bagian tumbuhan obat sebagai cara pengolahan tertinggi juga ditemukan pada wilayah lain di Kabupaten Kayong Utara seperti yang dilaporkan oleh Aminah et al., (2016) di desa Sejahtera, Ardiana et al., (2019) di desa Teluk Batang, dan Rania et al., (2019) di desa Masbangun. Perebusan diduga merupakan cara cepat dalam mengeluarkan berbagai komponen senyawa bioaktif yang dimiliki oleh tanaman (Rania et al., 2019; Jani et al., 2019), dan dapat lebih enak dalam mengkomsinya karena dengan merebus dapat menghilangkan aroma mentah yang dimiliki oleh tanaman (Jani et al., 2019).

\section{Penggunaan Tumbuhan sebagai Obat Oleh Masyarakat Lokal}

Penggunaan tumbuhan obat oleh masyarakat desa Rantau Panjang dengan cara ditempel, dimakan, diminum, dioles, ditetes dan dikunyah. Dari keenam cara penggunaan 
tersebut, yang paling banyak digunakan yaitu dengan cara diminum $(60,86 \%)$, dan ditempel $(34,78 \%)$ (Gambar 4).

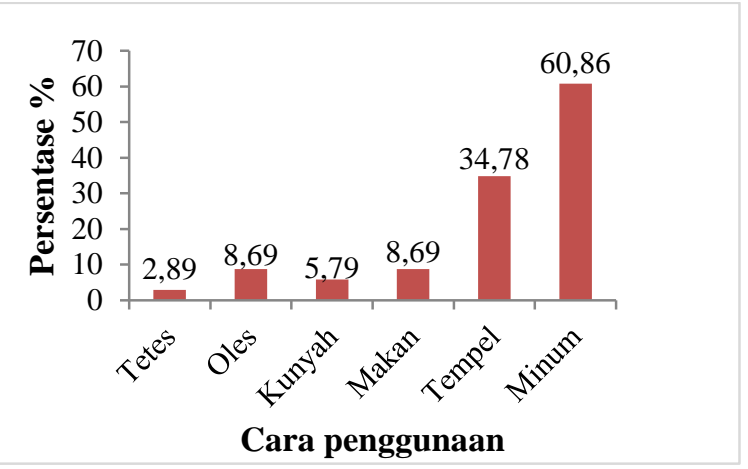

Gambar 4. Teknik penggunaan tumbuhan obat oleh masyarakat desa Rantau Panjang

Penggunaan diminum sebagai cara pengunaan tertinggi juga dilakukan oleh masyarakat diwilayah lain di Kabupaten Kayong Utara seperti yang dilaporkan oleh Rania et al., (2019) di desa Masbangun dan Sauji et al., (2019) di desa Gunung Sembilan. Diduga dengan cara meminum tumbuhan obat, aktivitas maupun efektivitas dalam pengobatan lebih baik dan lebih cepat jika dikomparasikan dengan cara yang lain, walaupun cara penggunaan tersebut tergantung pada kategori penyakit yang diderita (Yusro et al., 2019).

\section{Fidelity Level (FL)}

Jenis-jenis tanaman yang paling dipilih/disukai oleh masyarakat untuk pengobatan kategori penyakit tertentu ditunjukkan dengan nilai Fidelity level (FL) (Sarquis et al., 2019). Nilai Fidelity level (FL) tertinggi (100\%) dari 29 kategori penyakit terdapat pada jenis tanaman simpur dan ketumbar untuk perawatan paska persalinan melahirkan; sawo dan leban untuk mengobati sakit perut; pulai untuk sakit gigi; jantung pisang untuk melancarkan menstruasi; bunga raya, alalang, durian dan nipah untuk demam panas; kopi, selo daging, dan keladi untuk luka; paku ikan dan pegage untuk jerawat; kumis kucing untuk melancarkan buang air kecil; mahkota dewa dan belange untuk sakit kepala; belimbing wuluh, asam jawa, andong, limau sambal, jambu biji untuk batuk; lidah buaya, pinang untuk pembengkakan; mentimun dan daun salam untuk menurunkan darah; manggis dan bajakah untuk kanker; cempedak untuk mengatasi malaria; pandan wangi dan pasak bumi untuk mengatasi pegal-pegal; tebu merah dan jengkol untuk memperkuat gigi; anggrek untuk sakit telinga; cengkodok untuk sariawan dan ketepeng untuk penyakit kurap (Tabel 2).

Beberapa jenis tumbuhan obat dengan FL tertinggi diketahui mengandung beberapa komponen senyawa yang berfungsi dalam pengobatan seperti pada tanaman simpur (Dillenia indica) mengandung alkaloid, phenolik, dan flavonoid yang berpotensi sebagai antioksidan (Alam et al., 2020). Sawo (Manilkara zapota) mengandung flavonoid, tanin, phenolik, flavanol, kaempferol (Pravin \& Shashikant, 2019), dan pulai (Alstonia scholaris) mengandung alkaloid, flavonoid, tanin, steroid, saponin, dan triterpenoid (Zuraida \& Sulistiyani, 2020). Adanya kelompok senyawa bioaktif jenisjenis tumbuhan obat tersebut diduga yang memberikan efek pengobatan terhadap beberapa kategori penyakit yang diderita oleh masyarakat desa Rantau Panjang. 
Tabel 1. Ragam jenis tumbuhan obat yang dimanfaatkan oleh masyarakat desa Rantau Panjang kabupaten Kayong Utara

\begin{tabular}{|c|c|c|c|c|c|c|c|c|}
\hline No. & Nama lokal & Nama latin & Famili & Khasiat & $\begin{array}{l}\text { Bagian } \\
\text { tanaman }\end{array}$ & $\begin{array}{l}\text { Cara } \\
\text { pengolahan }\end{array}$ & $\begin{array}{l}\text { Cara } \\
\text { penggunaan }\end{array}$ & $\mathbf{U V}$ \\
\hline 1 & Alalang & Imperata cylindrica $\mathrm{L}$ & Poaceae & Demam & Akar & Rebus & Minum & 0,1 \\
\hline 2 & Asam jawa & Tamarindus indica $\mathrm{L}$ & Fabaceae & Batuk & Buah & Rebus & Minum & 0,1 \\
\hline 3 & Api-api & Loranthus $\mathrm{L}$ & Loranthaceae & Kanker, demam panas & Akar & Rebus & Minum & 0,06 \\
\hline 4 & Andong & Cordyline fruticosa $\mathrm{L}$ & Asparagaceae & Batuk & Daun & Rebus & Minum & 0,01 \\
\hline 5 & Ati-ati & $\begin{array}{l}\text { Solenostemon } \\
\text { scutellarioides } \mathrm{L}\end{array}$ & Lamiaceae & $\begin{array}{l}\text { Batuk, melancarkan } \\
\text { menstruasi }\end{array}$ & Daun & Rebus & Minum & 0,05 \\
\hline 6 & Anggrek & Dendrobium crumenatum L & Orchidaceae & Sakit telinga & Rimpang & Rebus & Teteskan & 0,02 \\
\hline 7 & Bawang merah & Allium сера $\mathrm{L}$ & Amaryllidaceae & $\begin{array}{l}\text { Demam panas, gatal-gatal, } \\
\text { luka }\end{array}$ & Umbi & $\begin{array}{l}\text { Tidak diolah, } \\
\text { tumbuk }\end{array}$ & Tempel, oles & 0,12 \\
\hline 8 & Bawang putih & Allium sativum Linn & Amaryllidaceae & $\begin{array}{l}\text { Sakit gigi, sakit perut, gatal- } \\
\text { gatal, membersihkan kutu } \\
\text { dirambut }\end{array}$ & Umbi & $\begin{array}{l}\text { Bakar, tidak } \\
\text { diolah }\end{array}$ & $\begin{array}{l}\text { Kunyah, } \\
\text { tempel }\end{array}$ & 0,12 \\
\hline 9 & Bawang serati & Eleutherine bulbosa $\mathrm{L}$ & Iridaceae & $\begin{array}{l}\text { Kanker, luka, darah tinggi, } \\
\text { menurunkan darah }\end{array}$ & $\begin{array}{l}\text { Umbi dan } \\
\text { daun }\end{array}$ & Rebus & Minum & 0,08 \\
\hline 10 & Bajakah & Spatholobus littoralis Hassk & Menispermaceae & Kanker & Akar & Rebus & Minum & 0,02 \\
\hline 11 & Belange & Caesalpinia bonduc $\mathrm{L}$ & Caesalpiniaceae & Sakit kepala & Akar & Rebus & Minum & 0,03 \\
\hline 12 & Bemban & $\begin{array}{l}\text { Donax canniformis } \mathrm{K} . \\
\text { Schum }\end{array}$ & Marantaceae & Sakit mata & Daun & Rebus & Teteskan & 0,03 \\
\hline 13 & Bonglai & Zingiber montanum Roxb & Zingiberaceae & Pilek, dan batuk & Rimpang & Parut & Minum & 0,11 \\
\hline 14 & Bunge raye & Hibiscus rosa-sinensis $\mathrm{L}$ & Malvaceae & Demam panas & Daun & Ramas & Tempelkan & 0,12 \\
\hline 15 & $\begin{array}{l}\text { Belimbing } \\
\text { wuluh }\end{array}$ & Averrhoa bilimbi & Oxalidaceae & Batuk & Buah & Rebus & Minum & 0,02 \\
\hline 16 & Cekor & Kaempferia galanga $\mathrm{L}$ & Zingiberaceae & $\begin{array}{l}\text { Pegal-pegal, batuk, } \\
\text { menurunkan darah }\end{array}$ & Rimpang & Rebus, parut & $\begin{array}{l}\text { Minum, } \\
\text { tempel }\end{array}$ & 0,12 \\
\hline 17 & Cempedak & Artocarpus integer $\mathrm{L}$ & Moraceae & Malaria & Buah & Kupas & Makan & 0,01 \\
\hline 18 & Cengkodok & Melastoma malabathrium L & Melastomataceae & Sariawan & Buah & Tidak diolah & $\begin{array}{l}\text { Makan, } \\
\text { tempel }\end{array}$ & 0,02 \\
\hline 19 & Daun salam & Syxygium polyanthum Walp & Myrtaceae & Menurunkan darah & Daun & Rebus & Minum & 0,03 \\
\hline 20 & Durian & Durio zibethinus Rumph & Malvaceae & Demam & Daun & Remas & Tempel & 0,03 \\
\hline 21 & Jeruju & Acanthus ilicifolius $\mathrm{L}$ & Acanthaceae & Jerawat & Buah & Tumbuk & Tempel & 0,06 \\
\hline 22 & Jambu biji & Psidium guajava $\mathrm{L}$ & Myrtaceae & Batuk & Daun & Rebus & Minum & 0,12 \\
\hline 23 & Jahe & Zingiber officinale Roxb & Zingiberaceae & $\begin{array}{l}\text { Pegal-pegal, batuk, sakit } \\
\text { kepala }\end{array}$ & Rimpang & Rebus & Minum & 0,19 \\
\hline
\end{tabular}


Saupi, M. et al. (2021). Jurnal Biologi Tropis, 21 (3): $805-817$ DOI: http://dx.doi.org/10.29303/jbt.v21i3.2949

\begin{tabular}{|c|c|c|c|c|c|c|c|c|}
\hline No. & Nama lokal & Nama latin & Famili & Khasiat & $\begin{array}{l}\text { Bagian } \\
\text { tanaman }\end{array}$ & $\begin{array}{l}\text { Cara } \\
\text { pengolahan }\end{array}$ & $\begin{array}{l}\text { Cara } \\
\text { penggunaan }\end{array}$ & $\mathbf{U V}$ \\
\hline 24 & Jengkol & $\begin{array}{l}\text { Archidendron pauciflorum } \\
\mathrm{L}\end{array}$ & Fabaceae & Memperkuat gigi & Buah & Kupas & Kunyah & 0,01 \\
\hline 25 & Jantung pisang & Musa acuminata $\mathrm{L}$ & Musaceae & Melancarkan menstruasi & Buah & Rebus & Makan & 0,03 \\
\hline 26 & Kunyit putih & Curcuma zedoaria L & Zingiberaceae & $\begin{array}{l}\text { Perawatan paska melahirkan, } \\
\text { batuk, sakit tenggorokan, } \\
\text { gatal-gatal, melancarkan } \\
\text { menstruasi, sakit perut }\end{array}$ & Rimpang & $\begin{array}{l}\text { Rebus dan } \\
\text { parut }\end{array}$ & Minum & 0,28 \\
\hline 27 & Kelapa & Cocos nucifera $\mathrm{L}$ & Palmaceae & $\begin{array}{l}\text { Demam panas, melancarkan } \\
\text { buang air kecil }\end{array}$ & Buah & Tidak di olah & Minum & 0,1 \\
\hline 28 & Keladi & Colocasia esculenta $\mathrm{L}$ & Araceae & Luka & Umbi & Tumbuk & Tempel & 0,02 \\
\hline 29 & Ketumbar & Coriandrum sativum $\mathrm{L}$ & Apiaceae & $\begin{array}{l}\text { Perawatan paska melahirkan, } \\
\text { pembengkakan }\end{array}$ & Umbi & $\begin{array}{l}\text { Rebus dan } \\
\text { tumbuk }\end{array}$ & Minum & 0,02 \\
\hline 30 & Kunyit & Curcuma longa $\mathrm{L}$ & Zingiberaceae & $\begin{array}{l}\text { Perawatan paska melahirkan, } \\
\text { sakit perut, luka, } \\
\text { melancarkan menstruasi }\end{array}$ & Rimpang & Tumbuk, rebus & $\begin{array}{l}\text { Minum, } \\
\text { tempel }\end{array}$ & 0,42 \\
\hline 31 & Kopi & Coffe canephora pierra $\mathrm{L}$ & Rubiaceae & Luka & Buah & Tumbuk & Tempel & 0,03 \\
\hline 32 & Ketiping & Senna alata $\mathrm{L}$ & Fabaceae & Gatal-gatal & Daun & Tumbuk & Oles, tempel & 0,08 \\
\hline 33 & Kacang kuning & Vigna sinensis $\mathrm{L}$ & Fabaceae & Tipes & Daun & Rebus & Minum & 0,04 \\
\hline 34 & Kumis kucing & Oethosiphon aristatus Miq & Lamiaceae & Melancarakan buang air kecil & Daun & Rebus & Minum & 0,06 \\
\hline 35 & Leletop & Physallis peruviana $\mathrm{L}$ & Solanaceae & Sakit perut, malaria, batuk & $\begin{array}{l}\text { Akar dan } \\
\text { buah }\end{array}$ & Rebus & Minum & 0,11 \\
\hline 36 & Lidah buaya & Aloe vera $\mathrm{L}$ & Asphdelaceae & Pembengkakan & Daun & Tidak diolah & Tempelkan & 0,06 \\
\hline 37 & Leban & Vitex pinnata $\mathrm{L}$ & Verbenaceae & Sakit perut & Daun & Rebus & Minum & 0,03 \\
\hline 38 & Lelaet & Ziziphus elegans $\mathrm{L}$ & Anisophylleaceae & $\begin{array}{l}\text { Serangan jantung, demam } \\
\text { panas, pegal-pegal, }\end{array}$ & Akar & Rebus & Minum & 0,03 \\
\hline 39 & Lengkuas & Alpinia galanga $\mathrm{L}$ & Zingiberaceae & Kolestrol, batuk, luka & Rimpang & Rebus & Minum & 0,11 \\
\hline 40 & Labu air & $\begin{array}{l}\text { Legenaria siceraria } \\
\text { (Molina) Standl }\end{array}$ & Cucurbitaceae & Demam panas, tipes, & Buah & Parut & Tempelkan & 0,19 \\
\hline 41 & Limau nipis & Citrus aurantifolia Swing & Rutaceae & Batuk, dan sakit tenggorokan & Buah & Tidak diolah & $\begin{array}{l}\text { Oles, tempel, } \\
\text { kunyah }\end{array}$ & 0,16 \\
\hline 42 & Limau sambal & Citrus amblycarpa Ochse & Rutaceae & Batuk & Buah & Tidak diolah & Kunyah & 0,11 \\
\hline 43 & Liyak merah & Zingiber officinale Linn & Zingiberaceae & $\begin{array}{l}\text { Keseleo, pembengkakan, } \\
\text { keputihan, sakit kepala, } \\
\text { batuk, pilek, perawatan pasca } \\
\text { melahirkan }\end{array}$ & Rimpang & Rebus, parut & $\begin{array}{l}\text { tempel, } \\
\text { minum }\end{array}$ & 0,34 \\
\hline 44 & Manggis & Garcinia mangostana $\mathrm{L}$ & Clusiaciae & Kanker & $\begin{array}{l}\text { Kulit, dan } \\
\text { buah }\end{array}$ & Rebus & Minum & 0,02 \\
\hline
\end{tabular}


Saupi, M. et al. (2021). Jurnal Biologi Tropis, 21 (3): $805-817$ DOI: http://dx.doi.org/10.29303/jbt.v21i3.2949

\begin{tabular}{|c|c|c|c|c|c|c|c|c|}
\hline No. & Nama lokal & Nama latin & Famili & Khasiat & $\begin{array}{l}\text { Bagian } \\
\text { tanaman }\end{array}$ & $\begin{array}{l}\text { Cara } \\
\text { pengolahan }\end{array}$ & $\begin{array}{l}\text { Cara } \\
\text { penggunaan }\end{array}$ & $\mathbf{U V}$ \\
\hline 45 & Mengkudu & Morinda citrifolia $\mathrm{L}$ & Rubiaceae & Demam dan kanker & Daun & Rebus & Minum & 0,09 \\
\hline 46 & Mahkota dewa & $\begin{array}{l}\text { Phaleria macrocarpa } \\
\text { (Scheff) }\end{array}$ & Thymelaeaceae & Sakit kepala & Daun & Rebus & Minum & 0,08 \\
\hline 47 & $\begin{array}{l}\text { Mentemu } \\
\text { lawak }\end{array}$ & $\begin{array}{l}\text { Boerl.Curcuma Xanthorriza } \\
\text { Roxb }\end{array}$ & Zingiberaceae & $\begin{array}{l}\text { Pilek, pegal-pegal, } \\
\text { pembengkakan, kolestrol, } \\
\text { melancarkan menstruasi, } \\
\text { luka }\end{array}$ & Rimpang & Rebus, parut & $\begin{array}{l}\text { Minum, } \\
\text { tempel }\end{array}$ & 0.18 \\
\hline 48 & Mentimun & Cucumis sativus $\mathrm{L}$ & Cucurbitaceae & Menurunkan darah & Buah & Tidak di olah & Makan & 0,05 \\
\hline 49 & Nipah & Nypa fruticans & Arecaceae & Demam panas & Buah & Rebus & Minum & 0,03 \\
\hline 50 & Sirsak & Annona muricata $\mathrm{L}$ & Anonnaceae & $\begin{array}{l}\text { Kolestrol, serangan jantung, } \\
\text { membersihkan kutu } \\
\text { dirambut, }\end{array}$ & Daun & Rebus, tumbuk & Minum & 0,08 \\
\hline 51 & Pasak bumi & Eurycoma longifolia Jack & Simaroubaceae & Pegal-pegal, & Akar & Rebus & Minum & 0,06 \\
\hline 52 & Pinang & Areca catachu $\mathrm{L}$ & Arecaceae & Pembengkakan & Buah & Tumbuk & Tempel & 0,04 \\
\hline 53 & Pepaya & Carica papaya $\mathrm{L}$ & Caricaceae & $\begin{array}{l}\text { Malaria, menurunkan darah, } \\
\text { sakit tenggorokan }\end{array}$ & Daun & Rebus & Minum & 0,15 \\
\hline 54 & Pandan wangi & $\begin{array}{l}\text { Pandanus amaryllifolius } \\
\text { Roxb }\end{array}$ & Pandanaceae & Pegal-pegal & Daun & Rebus, tumbuk & Minum, oles & 0,03 \\
\hline 55 & Pata wali & Tinospora crispa L & Menispermaceae & $\begin{array}{l}\text { Pegal-pegal, demam panas, } \\
\text { sakit tenggorokan }\end{array}$ & Akar & Rebus & Minum & 0,06 \\
\hline 56 & Paku ikan & Athyrium filix femin $\mathrm{L}$ & Tracheophyta & Jerawat & Daun & Tumbuk & Tempel & 0,05 \\
\hline 57 & Putri malu & Mimosa pudica L & Fabaceae & $\begin{array}{l}\text { Batuk, melancarkan buang } \\
\text { air kecil }\end{array}$ & Akar & Rebus & Minum & 0,03 \\
\hline 58 & Peria & $\begin{array}{l}\text { Momordica charantia } \\
\text { Descourt }\end{array}$ & Cucurbitaceae & $\begin{array}{l}\text { Menurunkan darah, demam } \\
\text { panas, luka }\end{array}$ & Daun & Rebus & Minum & 0,15 \\
\hline 59 & Pegage & Cantella asiatica $\mathrm{L}$ & Mackinalayaceae & Jerawat & Daun & Rebus & Minum & 0,07 \\
\hline 60 & Pulai & Alstonia scholaris $\mathrm{L}$ & Apocynaceae & Sakit gigi & Batang & Tidak diolah & Oles & 0,06 \\
\hline 61 & Sirih & Piper betle L & Piperaceae & $\begin{array}{l}\text { Sakit mata, melancarkan } \\
\text { menstruasi, batuk, dan } \\
\text { keputihan }\end{array}$ & Daun & Rebus, giling & $\begin{array}{l}\text { Minum, } \\
\text { tempel }\end{array}$ & 0,22 \\
\hline 62 & Sawo & Manilkara zapota $\mathrm{L}$ & Sapotaceae & Sakit perut, & Buah & Tidak di olah & Makan & 0,02 \\
\hline 63 & Simpur & Dillenia indica $\mathrm{L}$ & Dilleniaceae & Perawatan pasca melahirkan, & Daun & Rebus, tumbuk & $\begin{array}{l}\text { Minum, } \\
\text { tempel }\end{array}$ & 0,01 \\
\hline 64 & Serai & Cymbopogon citrates & Poaceae & Batuk, demam panas, keseleo & Batang & Tumbuk & $\begin{array}{l}\text { Tempel dan } \\
\text { minum }\end{array}$ & 0,12 \\
\hline 65 & Selo daging & Gynura procumbens Lour & Asteraceae & Luka & Daun & Giling & Tempel & 0,06 \\
\hline
\end{tabular}


Saupi, M. et al. (2021). Jurnal Biologi Tropis, 21 (3): 805 - 817 DOI: http://dx.doi.org/10.29303/jbt.v21i3.2949

\begin{tabular}{|c|c|c|c|c|c|c|c|c|}
\hline No. & Nama lokal & Nama latin & Famili & Khasiat & $\begin{array}{l}\text { Bagian } \\
\text { tanaman }\end{array}$ & $\begin{array}{l}\text { Cara } \\
\text { pengolahan }\end{array}$ & $\begin{array}{l}\text { Cara } \\
\text { penggunaan }\end{array}$ & $\mathbf{U V}$ \\
\hline 66 & Sirih merh & Piper decumanum L & Piperaceae & $\begin{array}{l}\text { Batuk, sakit mata, demam } \\
\text { panas }\end{array}$ & Daun & Rebus, giling & $\begin{array}{l}\text { Minum, } \\
\text { tempel }\end{array}$ & 0,12 \\
\hline 67 & Sirih pedas & Piper betle L & Piperaceae & Sakit mata, sariawan & Daun & Salai & Tempel & 0,09 \\
\hline 68 & Tebu merah & Saccharum officinarum L & Poaceae & Memperkuat gigi & Batang & Tidak diolah & Kunyah & 0,03 \\
\hline 69 & Ubi kayu & Manihot utilisima Pohl & Euphorbiaceae & $\begin{array}{l}\text { Menurunkan darah, gatal- } \\
\text { gatal, demam panas }\end{array}$ & Umbi & Parut & $\begin{array}{l}\text { Tempel dan } \\
\text { makan }\end{array}$ & 0,16 \\
\hline
\end{tabular}


Tabel 2. Fidelity Level (FL) jenis-jenis tumbuhan obat yang dimanfaatkan masyarakat desa Rantau Panjang

\begin{tabular}{|c|c|c|}
\hline No & Kategori penyakit & Fidelity level (\%) \\
\hline 1 & Paska persalinan melahirkan & $\begin{array}{l}\text { Kunyit }(31,72 \%) \text {, simpur }(100 \%) \text {, ketumbar }(100 \%) \text {, kunyit putih } \\
(21,27 \%) \text {, jahe merah }(30,43 \%)\end{array}$ \\
\hline 2 & Sakit perut & $\begin{array}{l}\text { Kunyit }(15,86 \%) \text {, bawang putih }(33,33 \%) \text {, leletop }(41,02 \%) \text {, sawo } \\
(100 \%) \text {, kunyit putih }(15,95 \%) \text {, leban }(100 \%)\end{array}$ \\
\hline 3 & Sakit gigi & Pulai $(100 \%)$, bawang putih $(40,47 \%)$ \\
\hline 4 & Melancarkan menstruasi & $\begin{array}{l}\text { Kunyit }(23,44 \%) \text {, metemu lawak }(31,16 \%) \text {, ati-ati }(61,11 \%) \\
\text { jantung pisang }(100 \%) \text {, sirih }(14,86 \%) \text {, kunyit putih }(27,65 \%)\end{array}$ \\
\hline 5 & Demam panas & $\begin{array}{l}\text { Bunga raye }(100 \%) \text {, bawang merah }(32,5 \%,) \text { kelapa }(68,57 \%) \\
\text { alalang }(100 \%) \text {, durian }(100 \%) \text {, lelaet }(23,07 \%) \text {, api-api }(59,09 \%) \text {, } \\
\text { patawali }(14,28 \%) \text {, serai }(14,28) \text {, nipah }(100 \%) \text {, mengkudu } \\
(70,83 \%) \text {, peria }(36 \%) \text {, labu air }(40,9 \%) \text {, } \\
\text { kacang kuning }(43,75 \%) \text {, sirih merah }(7,14 \%) \text {, ubi kayu }(16,07 \%)\end{array}$ \\
\hline 6 & Luka & $\begin{array}{l}\text { Kunyit }(8,96 \%) \text {, bawang merah }(50 \%) \text {, keladi }(100 \%) \text {, kopi } \\
(100 \%) \text {, bawang serati }(29,62 \%) \text {, jantung pisang }(100 \%) \text {, selo } \\
\text { daging }(100 \%) \text {, mentemu lawak }(11,47 \%) \text {, peria }(6 \%) \text {, lengkuas } \\
(40,54 \%)\end{array}$ \\
\hline 7 & Gatal-gatal & $\begin{array}{l}\text { Kunyit putih }(15,95 \%) \text {, bawang merah }(50 \%) \text {, } \\
\text { bawang putih }(16,66 \%) \text {, ubi kayu }(21,42 \%)\end{array}$ \\
\hline 8 & Jerawat & Paku ikan (100\%), pegage $(100 \%)$ \\
\hline 9 & Kolestrol & $\operatorname{Sirsak}(54,83 \%)$, mentemu lawak $(8,19 \%)$ \\
\hline 10 & Melancarkan buang air kecil & Kelapa $(31,42 \%)$, kumis kucing $(100 \%)$, putri malu $(75 \%)$ \\
\hline 11 & Sakit kepala & $\begin{array}{l}\text { Mahkota dewa }(100 \%) \text { belange }(100 \%) \text {, jahe }(23,43 \%) \text {, jahe } \\
\text { merah }(15,65 \%)\end{array}$ \\
\hline 12 & Batuk & $\begin{array}{l}\text { Sirih }(23,61) \text {, belimbing wuluh }(100 \%) \text {, asam jawa }(100) \text {, andong } \\
(100 \%) \text { putri malu }(25 \%) \text {, serai }(26,19 \%) \text {, lengkuas }(18,91 \%) \text {, } \\
\text { ati-ati } \\
(38,88 \%) \text {, jahe }(10,93 \%) \text {, cekor }(37,20 \%) \text {, bunglai }(60 \%) \text {, limau } \\
\text { nipis }(76,78 \%) \text {, limau sambal }(100 \%) \text {, sirih merah }(30,95 \%) \text {, jahe } \\
\text { merah }(12,17 \%) \text {, jambu biji }(100 \%) \text {, kunyit putih }(15,95 \%) \text {, } \\
\text { leletop }(30,76 \%)\end{array}$ \\
\hline 13 & Pembengkakan & $\begin{array}{l}\text { Kunyit }(20 \%) \text {, lidah buaya }(100 \%) \text {, mentemu lawak }(11,47 \%) \text {, } \\
\text { jahe merah }(7,82 \%) \text {, pinang }(100 \%)\end{array}$ \\
\hline 14 & Serangan jantung & Sirsak $(22,58 \%)$, lelaet $(38,46 \%)$ \\
\hline 15 & Membersihkan kutu di rambut & Sirsak $(22,58 \%)$, bawang putih $(4,76 \%)$ \\
\hline 16 & Pilek & $\begin{array}{l}\text { Mentemu lawak }(11,47 \%) \text {, bunglai }(39,47 \%) \text {, jahe merah } \\
(14,78 \%)\end{array}$ \\
\hline 17 & Sakit mata & $\begin{array}{l}\text { Sirih }(47,22 \%) \text {, bemban }(100 \%) \text {, sirih merah }(61,90 \%) \text {, sirih pedas } \\
(51,61 \%)\end{array}$ \\
\hline 18 & Menurunkan darah & $\begin{array}{l}\text { Ubi kayu }(62,5 \%) \text {, pepaya }(58,49 \%) \text {, daun salam }(100 \%) \text {, peria } \\
(58 \%) \text {, mentimun }(100 \%) \text {, bawang serati }(40,47 \%) \text {, cekor } \\
(18,60 \%)\end{array}$ \\
\hline 19 & Kanker & $\begin{array}{l}\text { Bawang serati }(29,62 \%) \text {, manggis }(100 \%) \text {, mengkudu }(29,16 \%) \text {, } \\
\text { bajakah }(100 \%) \text {, api-api }(40,90 \%)\end{array}$ \\
\hline 20 & Malaria & Leletop $(28,20 \%)$, pepaya $(24,52 \%)$, cempedak $(100 \%)$. \\
\hline 21 & Sakit tenggorokan & $\begin{array}{l}\text { Pepaya }(16,98 \%) \text {, pata wali }(33,33 \%) \text {, limau nipis }(32,21 \%) \text {, } \\
\text { kunyit putih }(3,19 \%)\end{array}$ \\
\hline 22 & Tipes & Kacang $(56,25 \%)$, labu air $(59,09 \%)$ \\
\hline 23 & Keputihan & Jahe merah $(695 \%)$, sirih $(16,66 \%)$ \\
\hline 24 & Keseleo & Serai $(59,52 \%)$, jahe merah $(12,17 \%)$ \\
\hline 25 & Pegal-pegal & $\begin{array}{l}\text { Pandan wangi }(100 \%) \text {, lelaet }(38,46 \%) \text {, pata wali }(66,66 \%) \text {, jahe } \\
(65,62 \%) \text {, cekor }(44,18 \%) \text {, mentemu lawak }(37,70 \%) \text {, pasak bumi } \\
(100 \%) \text {, }\end{array}$ \\
\hline 26 & Memperkuat gigi & Tebu merah (100\%), jengkol (100\%) \\
\hline 27 & Sariawan & Cengkodok $(100 \%)$, sirih pedas $(48,38 \%)$ \\
\hline
\end{tabular}




\begin{tabular}{|c|c|c|}
\hline & Kategori penyakit & Fidelity level (\%) \\
\hline 28 & Sakit telinga & Anggrek (100\%) \\
\hline 29 & Kurap & Ketepeng $(100 \%)$ \\
\hline
\end{tabular}

\section{Kesimpulan}

Masyarakat desa Rantau Panjang Kabupaten Kayong Utara memiliki kearifan lokal dalam memanfaatkan tumbuhan obat. Kearifan lokal tersebut tercermin dari beragamnya jenis tumbuhan obat yang digunakan dan adanya tanaman-tanaman jenis tertentu yang dipilih/disukai untuk mengatasi berbagai macam kategori penyakit. Kearifan lokal ini harus terus dipertahankan dan diwariskan kepada generasi selanjutnya, baik secara lisan ataupun dalam bentuk tulisan sehingga pengetahuan tumbuhan obat tidak hilang seiring dengan kemajuan pengetahuan obat modern.

\section{Ucapan Terima Kasih}

Ucapan terima kasih kami sampaikan kepada Kepala Desa dan perangkatnya serta masyarakat desa Rantau Panjang yang telah membantu terlaksananya penelitian ini.

\section{References}

Agung, Suleman, S. M., \& Pitopang, R. (2018). Studi Etnobotani Tumbuhan Obat Pada Masyarakat Suku Kaili Rai Di Dusun Sisere, Desa Labuan Toposo, Kecamatan Labuan, Kabupaten Donggala, Sulawesi Tengah. Biocelebes, 12(2), 1-13. https://bestjournal.untad.ac.id/index.php/B iocelebes/article/view/11560

Alam, M. B., Ahmed, A., Islam, S., Choi, H. J., Motin, M. A., Kim, S., \& Lee, S. H. (2020). Phytochemical Characterization of Dillenia indica 1. Bark by Paper Spray IonizationMass Spectrometry and Evaluation of its Antioxidant Potential against t-bhpInduced Oxidative Stress in Raw 264.7 cells. Antioxidants, 9(11), 1-15. https://doi.org/10.3390/antiox9111099

Aminah, S., Wardenaar, E., \& Muflihati. (2016). Tumbuhan Obat yang dimanfaatkan oleh Battra di Desa Sejahtera Kecamatan
Sukadana Kabupaten Kayong Utara. Jurnal Hutan Lestari, 4(3), 299-305. https://doi.org/10.26418/jhl.v4i3.16144

Ardiana, N., Mariani, Y., \& Tavita, G. E. (2019). Studi Pemanfaatan Tumbuhan Obat Berpotensi Sebagai Anti-Inflamasi Di Desa Teluk Batang Utara Kecamatan Teluk Batang Kabupaten Kayong Utara. Jurnal Hutan Lestari, 7(3), 1111-1129. https://doi.org/10.26418/jhl.v7i3.37266

Chumroenphat, T., Somboonwatthanakul, I., Saensouk, S., \& Siriamornpun, S. (2019). The Diversity of Biologically Active Compounds in the Rhizomes of Recently Discovered Zingiberaceae Plants Native to North Eastern Thailand. Pharmacognosy Journal, 11(5), 1014-1022. https://doi.org/10.5530/pj.2019.11.160

Danciu, C., Vlaia, L., Fetea, F., Hancianu, M., Coricovac, D. E., Ciurlea, S. A., Şoica, C. M., Marincu, I., Vlaia, V., Dehelean, C. A., \& Trandafirescu, C. (2015). Evaluation of Phenolic Profile, Antioxidant and Anticancer Potential of Two Main Representants of Zingiberaceae Family against B164A5 Murine Melanoma Cells. Biological Research, 48, 1-9. https://doi.org/10.1186/0717-6287-48-1

Irayanti, A., \& Yadnya Putra, A. . G. R. (2020). a Narrative Review of Zingiberaceae Family As Antibacterial Agent for Traditional Medication Based on Balinese Local Wisdom. Journal of Pharmaceutical Science and Application, 2(2), 66. https://doi.org/10.24843/jpsa.2020.v02.i02 .p04

Jani, K. A., Nono, K. M., \& Amalo, D. (2019). Inventarisasi Tumbuhan Obat Tradisional di Masyarakat Etnis Kempo, Desa Cunca Lolos, kecamatan Mbeliling, Kabupaten Manggarai Barat, NTT. Jurnal Biotropikal Sains, 16(1), 73-79. https://ejurnal.undana.ac.id/index.php/biotr 
opikal/issue/view/158

Kigen, G., Kamuren, Z., Njiru, E., Wanjohi, B., \& Kipkore, W. (2019). Ethnomedical Survey of the Plants Used by Traditional Healers in Narok County, Kenya. EvidenceBased Complementary and Alternative Medicine, https://doi.org/10.1155/2019/8976937

Liu, Y., Liu, J., \& Zhang, Y. (2019). Research Progress on Chemical Constituents of Zingiber officinale Roscoe. BioMed Research International, 2019. https://doi.org/10.1155/2019/5370823

Nayaka, N. M. D. M. W., Sasadara, M. M. V., Sanjaya, D. A., Yuda, P. E. S. K., Dewi, N. L. K. A. A., Cahyaningsih, E., \& Hartati, R. (2021). Piper betle (L): Recent Review of Antibacterial and Antifungal Properties, Safety Profiles, and Commercial Applications. Molecules, 26(8), 1-21. https://doi.org/10.3390/molecules2608232 1

Pradita, S., Mariani, Y., Wardenaar, E., \& Yusro, F. (2021). Pemanfaatan Tumbuhan Obat oleh Suku Dayak Paus dan Melayu untuk Perawatan Ibu dan Anak Pasca Persalinan di Desa Pengadang Kabupaten Sanggau Kalimantan Barat. Biodidaktika: Jurnal Biologi Dan Pembelajarannya, 16(1), 93110. http://dx.doi.org/10.30870/biodidaktika.v1 $6 \mathrm{i} 1.10805$

Pranaka, R. N., Yusro, F., \& Budiastutik, I. (2020). Pemanfaatan Tanaman Obat Oleh Masyarakat Suku Melayu Di Kabupaten Sambas. Jurnal Tumbuhan Obat Indonesia, 13(1), $1-24$. https://doi.org/10.22435/jtoi.v13i1.1887

Pravin, P. K., \& Shashikant, C. D. (2019). Manilkara zapota (L.) Royen Fruit Peel: A Phytochemical and Pharmacological review. Systematic Reviews in Pharmacy, 10(1), 11-14. https://doi.org/10.5530/srp.2019.1.2

Rania, Yusro, F., Wardenaar, E., \& Mariani, Y.
(2019). Studi Pemanfaatan Tumbuhan Obat oleh Pengobat Tradisional untuk Mengatasi Masalah Kewanitaan di Desa Masbangun Kecamatan Teluk Batang Kabupaten Kayong Utara. Jurnal Borneo Akcaya, 5(2), 84-94.

Sari, R. P., Yusro, F., \& Mariani, Y. (2021). Medicinal Plants Used by Dayak Kanayatn Traditional Healers in Tonang Village Sengah Temila District Landak Regency. Jurnal Biologi Tropis, 21(2), 324. https://doi.org/10.29303/jbt.v21i2.2557

Sarquis, R. do S. F. R., Sarquis, Í. R., Sarquis, I. R., Fernandes, C. P., Silva, G. A. da, Silva, R. B. L. e, Jardim, M. A. G., Sánchez-Ortiz, B. L., \& Carvalho, J. C. T. (2019). The Use of Medicinal Plants in the Riverside Community of the Mazagão River in the Brazilian Amazon, Amapá, Brazil: Ethnobotanical and Ethnopharmacological Studies. Evidence-Based Complementary and Alternative Medicine, 2019, 1-25. https://doi.org/10.1155/2019/6087509

Sauji, M., Oramahi, H. A., \& Idham, M. (2019). Pemanfaatan Tumbuhan Obat oleh Masyarakat Desa Gunung Sembilan Kecamatan Sukadana Kabupaten Kayong Utara. Jurnal Hutan Lestari, 7(1), 499-506. https://doi.org/10.26418/jhl.v7i1.32323

Tanvir, E. M., Hossen, M. S., Hossain, M. F., Afroz, R., Gan, S. H., Khalil, M. I., \& Karim, N. (2017). Antioxidant Properties of Popular turmeric (Curcuma longa) Varieties from Bangladesh. Journal of Food Quality, 2017. https://doi.org/10.1155/2017/8471785

Tariq, A., Mussarat, S., Adnan, M., Allah, E. F. A., Hashem, A., Alqarawi, A. A., \& Ullah, R. (2015). Ethnomedicinal Evaluation of Medicinal Plants Used against Gastrointestinal Complaints. BioMed Research International, 2015, 1-14. https://doi.org/10.1155/2015/892947

Yusro, F., Mariani, Y., \& Wardenaar, E. (2019). Pemanfaatan Tumbuhan Obat untuk Mengatasi Gangguan Sistem Pencernaan 
oleh Suku Dayak Iban: Studi Kasus di Kabupaten Kapuas Hulu Kalimantan Barat. Jurnal Borneo Akcaya, 5(1), 58-72.

Yusro, F., Mariani, Y., Wardenaar, E., \& Yanieta Arbiastutie. (2020). Database Tumbuhan Obat Tradisional Kalimantan Barat (H. A. Oramahi (ed.)). CV Mitra Natawana.

Yusro, F., Pranaka, R., Budiastutik, I., \& Mariani, Y. (2020a). Diversity of Medicinal Plants Used by Traditional Healers of Dayak Desa Tribe in the Villages of Kebong and Merpak, Sintang Regency. Jurnal Biologi Tropis, 20(3), 329 - 339. https://doi.org/10.29303/jbt.v20i3.2010

Yusro, F., Pranaka, R. N., Budiastutik, I., \& Mariani, Y. (2020b). Pemanfaatan Tumbuhan Obat oleh Masyarakat Sekitar Taman Wisata Alam (TWA) Bukit Kelam, Kabupaten Sintang, Kalimantan Barat. Jurnal Sylva Lestari, 8(2), 255-272. https://doi.org/http://dx.doi.org/10.23960/j s128255-272

Yusro, F., Rania, Mariani, Y., Wardenaar, E., \& Arbiastuti, Y. (2020). Bioma: jurnal biologi makassar. Jurnal Biologi Makasar, $5(2)$, 186-198. http://journal.unhas.ac.id/index.php/bioma

Zuraida, \& Sulistiyani. (2020). Screening Phytochemical Compound of Alstonia scholaris R.Br in Different Sites in Indonesia. IOP Conference Series: Earth and Environmental Science, 591(1). https://doi.org/10.1088/1755-

1315/591/1/012034 